\title{
Plutonium Measurements by Accelerator Mass Spectrometry at LLNL
}

\author{
J.E. McAninch, T.F. Hamilton, T.A. Brown, T.J. Jokela, \\ J.P. Knezovich, T.J. Ognibene, I.D. Proctor, M.L. Roberts, \\ E. Sideras-Haddad, J.R. Southon and J.S. Vogel
}

This article was submitted to

$8^{\text {th }}$ International Conference on Accelerator Mass Spectrometry Vienna, Austria

September 6-10, 1999

U.S. Department of Energy

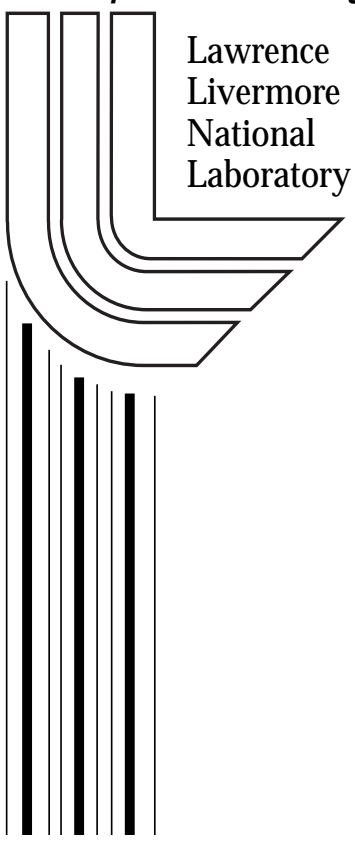

\section{October 26, 1999}




\section{DISCLAIMER}

This document was prepared as an account of work sponsored by an agency of the United States Government. Neither the United States Government nor the University of California nor any of their employees, makes any warranty, express or implied, or assumes any legal liability or responsibility for the accuracy, completeness, or usefulness of any information, apparatus, product, or process disclosed, or represents that its use would not infringe privately owned rights. Reference herein to any specific commercial product, process, or service by trade name, trademark, manufacturer, or otherwise, does not necessarily constitute or imply its endorsement, recommendation, or favoring by the United States Government or the University of California. The views and opinions of authors expressed herein do not necessarily state or reflect those of the United States Government or the University of California, and shall not be used for advertising or product endorsement purposes.

This is a preprint of a paper intended for publication in a journal or proceedings. Since changes may be made before publication, this preprint is made available with the understanding that it will not be cited or reproduced without the permission of the author.

This report has been reproduced directly from the best available copy.

Available to DOE and DOE contractors from the

Office of Scientific and Technical Information

P.O. Box 62, Oak Ridge, TN 37831

Prices available from (423) 576-8401

http:/ / apollo.osti.gov/bridge/

Available to the public from the National Technical Information Service

U.S. Department of Commerce 5285 Port Royal Rd., Springfield, VA 22161 http://www.ntis.gov/

OR

Lawrence Livermore National Laboratory Technical Information Department's Digital Library http://www.llnl.gov/tid/Library.html 


\title{
Plutonium measurements by accelerator mass spectrometry at LLNL
}

\author{
J.E. McAninch, ${ }^{\mathrm{a}, \dagger}$ T.F. Hamilton, ${ }^{\mathrm{b}}$ T.A. Brown, ${ }^{\mathrm{a}}$ T.A. Jokela, ${ }^{\mathrm{b}}$ \\ J.P. Knezovich, ${ }^{\text {a } T . J . ~ O g n i b e n e, ~}{ }^{a}$ I.D. Proctor, ${ }^{a}$ M.L. Roberts, ${ }^{a}$ \\ E. Sideras-Haddad, ${ }^{\mathrm{c}}$ J.R. Southon, ${ }^{\mathrm{a}}$ J.S. Vogel $^{\mathrm{a}}$ \\ a Center for Accelerator Mass Spectrometry, Lawrence Livermore National Laboratory, Livermore CA USA \\ b Health and Ecological Assessment Division, Lawrence Livermore National Laboratory, Livermore CA USA \\ c Schönland Research Centre for Nuclear Sciences, University of Witwatersrand, South Africa \\ $\dagger$ Corresponding author. Phone: 925423 8506. email: mcaninch1@1lnl.gov .
}

\begin{abstract}
Mass spectrometric methods provide sensitive, routine, and cost-effective analyses of longlived radionuclides. Here we report on the status of work at Lawrence Livermore National Laboratory (LLNL) to develop a capability for actinide measurements by accelerator mass spectrometry (AMS) to take advantage of the high potential of AMS for rejection of interferences. This work demonstrates that the LLNL AMS spectrometer is well-suited for providing high sensitivity, robust, high throughput measurements of plutonium concentrations and isotope ratios. Present backgrounds are $\sim 2 \times 10^{7}$ atoms per sample for environmental samples prepared using standard alpha spectrometry protocols. Recent measurements of ${ }^{239+240} \mathrm{Pu}$ and ${ }^{241} \mathrm{Pu}$ activities and ${ }^{240} \mathrm{Pu} /{ }^{239} \mathrm{Pu}$ isotope ratios in IAEA reference materials agree well with IAEA reference values and with alpha spectrometry and recently published ICP-MS results. Ongoing upgrades of the AMS spectrometer are expected to reduce backgrounds below $1 \times 10^{6}$ atoms per sample while allowing simplifications of the sample preparation chemistry. These simplifications will lead to lower per-sample costs, higher throughput, faster turn around and, ultimately, to larger and more robust data sets.
\end{abstract}




\section{Introduction}

Plutonium and other actinides are distributed throughout the environment as a result of nuclear weapons testing, fuel reprocessing, reactor operations and, to a lesser extent, accidental releases. ${ }^{1,2}$ Plutonium is found in fresh and sea waters, ${ }^{3,4}$ sediments, 5,6 aerosol particles, ice cores, and groundwaters. ${ }^{7}$ Because of the prevalence and potential health effects of these radionuclides, effort is devoted worldwide to actinide studies including basic actinide chemistry, environmental concentrations, speciation and partitioning, transport, evaluations of exposure pathways, ${ }^{1,8,9}$ toxicokinetic studies, ${ }^{10}$ bioassays of exposed populations, ${ }^{11-15}$ risk assessments, ${ }^{16}$ and nuclear non-proliferation and national security. ${ }^{17}$ Effects such as "hot" particles, ${ }^{18}$ resuspension, ${ }^{16}$ bioconcentration, ${ }^{19}$ and colloidal transport ${ }^{7}$ can complicate the transport, exposure pathways, and subsequent bioavailability. Daughters of pre-anthropogenic plutonium have also been studied for geochronology. ${ }^{20}$

Measurements provide the foundation for these activities, and the most commonly applied analytical tool is alpha spectrometry. Many applications, particularly those most relevant to human health effects, require significantly higher sensitivity than is available with alpha spectrometry ( $10^{8}$ atoms ${ }^{239,240} \mathrm{Pu}$ per sample). As examples: daily urinary excretions of $\mathrm{Pu}$ in the general population are $\sim 10^{6}$ atoms; ${ }^{11}$ plutonium bioassay programs require detection limits $\sim 10^{6}$ atoms per sample; ${ }^{14}$ mean plutonium concentrations in non-occupationally exposed persons are $\sim 10^{6}-10^{8}$ atoms per $\mathrm{g}$ of tissue; ${ }^{1}$ and plutonium concentrations resulting from global fallout in the surface waters of the open ocean are $\sim 10^{6}-10^{8}$ atoms per L. ${ }^{4,21}$ Alpha spectrometry also does not provide ${ }^{240} \mathrm{Pu} /{ }^{239} \mathrm{Pu}$ isotopic information, which is important for understanding systems with multiple sources. Depending on the source, ${ }^{240} \mathrm{Pu} /{ }^{239} \mathrm{Pu}$ ratios can vary from $<1 \%$ to greater than $30 \%$, and significant variations exist even within global fallout. 5

A number of analytical methods were developed as sensitive alternatives to alpha spectrometry. These are fission track analysis (FTA), 11,13,15,22-24 thermal ionization mass spectrometry (TIMS), 4,5,7,14,25,26 inductively coupled plasma-mass spectrometry (ICP-MS), ${ }^{27-33}$ 
and resonance ionization mass spectrometry (RIMS). ${ }^{34-37}$ All of these techniques have demonstrated sensitivities of $10^{6}-10^{8}$ atoms per sample, depending on the application and the level of interferences present, and all except FTA can provide ${ }^{240} \mathrm{Pu} /{ }^{239} \mathrm{Pu}$ isotopic ratios.

Recently, accelerator mass spectrometry (AMS) has been demonstrated for the ultratrace analysis of plutonium concentrations and isotope ratios. ${ }^{38,39}$ AMS is a well-established method for the detection of long-lived radionuclides ${ }^{40}$ and is an attractive alternative for plutonium measurements. AMS offers high efficiency, high rejection of interferences, low susceptibility to matrix components, and large dynamic range. These advantages may reduce demands on the sample preparation chemistry, which is a limiting factor for most other analytical methods. Ultimately AMS offers the potential combined benefits of high sample throughput and rapid analyses while maintaining low detection sensitivities of $\sim 1 \times 10^{6}$ atoms per sample for the plutonium isotopes ${ }^{239,240,241,242,244} \mathrm{Pu}$.

Capability for plutonium AMS measurements is under development at the Center for Accelerator Mass Spectrometry (CAMS) ${ }^{41}$ at Lawrence Livermore National Laboratory (LLNL).

\section{AMS measurements of plutonium at LLNL}

\section{Heavy Element Beamline}

Interference from uranium is a limiting factor in alpha spectrometry, FTA, and ICP-MS measurements of ${ }^{239} \mathrm{Pu}$. Chemical separation procedures developed for these methods can produce quite low uranium backgrounds $\left(10^{8}-10^{12}\right.$ atoms per sample); however, these procedures are relatively expensive and laborious and typically dominate the effort and expense for analyses. Uranium also presents an interference for AMS, and the major technical issue for AMS measurements of $\mathrm{Pu}$ is rejection of ${ }^{238} \mathrm{U}$ by the spectrometer. ${ }^{42}$ Actinide development at CAMS is therefore focussed on reducing this background through abundance sensitivity. The installation of a Heavy Element spectrometer (see Figure 1) is central to this development. ${ }^{42}$ Improved abundance sensitivity, and the resulting high rejection of ${ }^{238} \mathrm{U}$, provided by this spectrometer will 
ease the requirements placed on the sample preparation chemistry while reducing background at mass 239 to below $1 \times 10^{6}$ atoms per sample.

A prototype of the Heavy Element spectrometer was used for the work reported here. Abundance sensitivity with this arrangement is provided by the low- and high-energy analyzing magnets. A Wien velocity filter provides additional rejection of some interferences, but cannot resolve ${ }^{239} \mathrm{Pu}$ ions from the small fraction of ${ }^{238} \mathrm{U}$ ions which pass through the analyzing magnets. The final spectrometer, presently under construction, includes a $45^{\circ}$ cylindrical electrostatic analyzer (ESA) designed to remove the remaining ${ }^{238} \mathrm{U}$.

\section{Sample Preparation}

Sample preparation is based on the standard protocols used for alpha spectrometry in the LLNL Marshall Islands Program, ${ }^{43}$ with only minor modifications to provide a sample form appropriate for introduction into the ion source. $\mathrm{A}{ }^{242} \mathrm{Pu}$ spike is added to samples prior to digestion for isotope dilution normalization and yield measurement.

For the IAEA samples reported below, five $10 \%$ splits of the processed digest (in $\mathrm{HCl}$, following elution from the final column) were taken for AMS prior to electrodeposition onto alpha spectrometry planchets. AMS aliquots were combined with iron carrier $(1 \mathrm{mg} F e$ as iron nitrate in commercial atomic absorption standard solution); then precipitated with iron hydroxide by addition of high purity ammonium hydroxide. Following rinses, the precipitates were redissolved in high purity nitric acid; transferred to small quartz crucibles; taken to dryness; and baked at $800^{\circ} \mathrm{C}$. The resulting oxide was mixed with $\sim 1 \mathrm{mg}$ of high purity niobium powder, then pressed into a standard LLNL aluminum AMS sample holder.

\section{AMS Measurement}

A cesium sputter source ${ }^{44}$ was used to produce $28 \mathrm{keV}$ negative ions. The low energy spectrometer was sequentially cycled to accept the relevant analyte ions, ${ }^{239-242} \mathrm{Pu}^{16} \mathrm{O}^{-}$and ${ }^{238} \mathrm{U}^{16} \mathrm{O}^{-}$. The high energy spectrometer was set to select $5+$ ions at $39 \mathrm{MeV}$ energy, and the high 
energy analyzing magnet and Wien filter were cycled with the low energy spectrometer. At present, switching of the high energy magnet requires $\sim 30 \mathrm{~s}$, limiting precision and throughput. A gas ionization detector used for ion detection and particle identification allowed clean rejection of interfering ions at $4+$ and lower charge states.

The AMS results reported below consisted of a single cycle through the masses $(242,238$, $239,240,241,242)$ for each sample. Measurement time was typically $30 \mathrm{~s}$ per isotope, and less than 10 min per sample. Count rates at each mass, corrected for electronics deadtime, were normalized to the average 242 rate for that sample, then multiplied by the known ${ }^{242} \mathrm{Pu}$ spike activity. No corrections for uranium or other backgrounds, or for mass bias, were employed.

\section{Results}

Total spectrometer rejection of ${ }^{238} \mathrm{U}$ (abundance sensitivity) with the prototype spectrometer is $\sim 1-4 \times 10^{-5}$. The ESA is expected to improve abundance sensitivity by a factor of $10-100$, at which point abundance sensitivity is expected to be limited by other effects such as energy stability of the accelerator, ${ }^{238} \mathrm{U}^{16} \mathrm{O}^{1} \mathrm{H}^{-}$and ${ }^{238} \mathrm{U}^{17} \mathrm{O}^{-}$ion formation, and scattering in the high energy spectrometer. Ultimately, overall sensitivity is expected to be limited by $\mathrm{Pu}$ introduced during sample preparation (process blank).

For soil samples and reagent blanks, backgrounds with the prototype spectrometer are consistently $\sim 1-2 \times 10^{7}$ atoms per sample at masses 237 and 239 , limited by ${ }^{238} \mathrm{U}$ interference and possibly process blank. Backgrounds at masses 240 and 241 are $<5 \times 10^{6}$ atoms per sample, limited by counting efficiency for $30 \mathrm{~s}$ measurements. No other significant interferences were observed at masses 237, 239, 240, or 241. Total efficiency (detected counts per Pu atom in the sample) is $>2 \times 10^{-5}$ for 30 min measurements. Improvement by a factor of 2 or more can potentially be obtained with longer counting times and use of $4+$ ions. Improvements in the resolution of the low energy spectrometer may also allow the ion source to be run at higher output, further increasing count rates. 
Results for IAEA reference materials are shown in Tables 1 and 2. The results are compared to alpha spectrometry measurements, IAEA reference values, and to recent ICP-MS measurements reported by Muramatsu, et al. ${ }^{32}$ The ${ }^{239+240} \mathrm{Pu}$ activities as measured by AMS (Table 1) show a significant bias with increasing activity relative to the IAEA reference values (from $+20 \%$ to $-20 \%$ ). However, the AMS results agree with the corresponding alpha spectrometry aliquots, indicating that the bias is not related to the AMS measurement.

The instrumental precision/accuracy is limited by time-dependence in the negative ion output. A fast switching mode and multiple passes for each sample will be used for routine measurements and will average out this time-dependence. Ultimately, a precision of $1-3 \%$ is expected.

The AMS results for ${ }^{240} \mathrm{Pu} /{ }^{239} \mathrm{Pu}$ isotope ratios in IAEA-135 showed good agreement to the published ICP-MS results. Agreement (within the AMS uncertainties) was also obtained for IAEA Soil $6 .{ }^{241} \mathrm{Pu}$ activities were also measured in the samples to examine our capabilities for other isotopes, and good agreement was observed for IAEA-367, the only sample for which we had an independent measurement.

\section{Conclusions}

The present work demonstrates that the CAMS AMS spectrometer is well-suited for providing high sensitivity, robust, high throughput measurements of plutonium concentrations and isotope ratios. Present backgrounds are $\sim 2 \times 10^{7}$ atoms per sample for environmental samples prepared using standard alpha spectrometry protocols. Measurements of Pu concentrations and isotope ratios in IAEA reference materials showed good agreement with reference values, alpha spectrometry, and ICP-MS results. Installation of the ESA is expected to reduce background levels below $1 \times 10^{6}$ atoms per sample at masses 237, 239, 240, and 241 while allowing simplifications of the sample preparation chemistry. Additional hardware and software improvements will allow measurements of plutonium concentrations and ratios for >50 
unknowns in a $24 \mathrm{~h}$ period, which is typical for many of the long-lived radionuclides measured at CAMS.

\section{Acknowledgements}

The authors thank Drs. D.W. Layton, W.L. Robison, and J.C. Davis for their enthusiastic support of this work, and Dr. L.K. Fifield of the Australian National University for giving helpful suggestions which greatly sped up the development. This work was funded in part by the LLNL Directed Research and Development Program. This work was performed under the auspices of the US Department of Energy by Lawrence Livermore National Laboratory under contract W-7405-Eng-48. 


\section{Figure Captions}

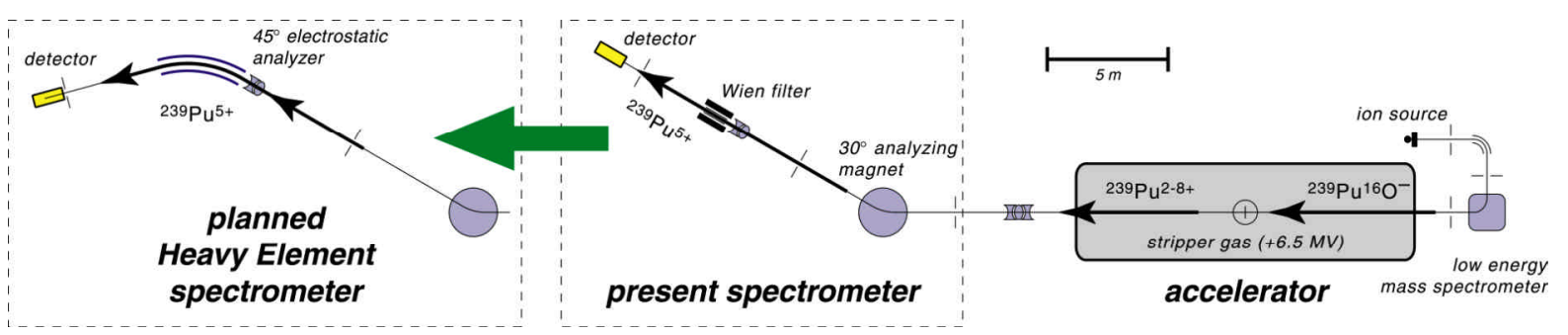

Figure 1 Accelerator mass spectrometry measurements of Pu isotopes at LLNL. Shown are the present setup, and planned upgrade (lower inset). In the present high energy spectrometer, a Wien filter is used to provide limited velocity analysis for the rejection of some interferences. In the final spectrometer, an electrostatic analyzer (cylindrical, $4.4 \mathrm{~m}$ radius, $5 \mathrm{~cm}$ plate gap, $45^{\circ}$ bending angle, $50 \mathrm{kV} / \mathrm{cm}$ maximum field) will provide the final separation of interferences. The ESA has been designed to fully resolve neighboring isotopes at $250 \mathrm{AMU}$. 
Table 1. Pu-239+240 activity concentrations. Recent measurements of ${ }^{239} \mathrm{Pu}+{ }^{240} \mathrm{Pu}$ activity concentrations (in $\mathrm{Bq} / \mathrm{kg}$ ) in IAEA reference materials by accelerator mass spectrometry (AMS) and alpha spectrometry at Lawrence Livermore National Laboratory. Two of five $10 \%$ aliquots (following sample digestion and chemical purification) were analyzed by AMS. One 50\% aliquot was analyzed by alpha spectrometry. The results are compared to IAEA reference values.

\begin{tabular}{|c|c|c|c|c|c|c|}
\hline $\begin{array}{c}\text { IAEA } \\
\text { Sample }\end{array}$ & $\begin{array}{c}\text { IAEA } \\
\text { reference } \\
(\mathbf{B q} / \mathbf{k g})\end{array}$ & $\begin{array}{c}\text { AMS } \\
\text { result }^{1} \\
\text { (Bq/kg) }\end{array}$ & $\begin{array}{c}\alpha \text {-spec } \\
\text { result } \\
(\mathrm{Bq} / \mathrm{kg})\end{array}$ & $\begin{array}{c}\text { AMS } \\
\text { / IAEA } \\
\%\end{array}$ & $\begin{array}{c}\alpha \text {-spec } \\
\text { / IAEA } \\
\%\end{array}$ & $\begin{array}{c}\text { Sample } \\
\text { Size }^{2} \\
(\mathrm{~g})\end{array}$ \\
\hline $\begin{array}{l}\text { IAEA-135 } \\
\text { (Irish Sea Sediment) }\end{array}$ & 213 & $\begin{array}{l}244 \pm 2 \\
246+2\end{array}$ & 252 & $\begin{array}{l}115 \% \\
115 \%\end{array}$ & $118 \%$ & 1 \\
\hline $\begin{array}{l}\text { IAEA-367 } \\
\text { (Pacific Ocean Sed.) }\end{array}$ & 38 & $\begin{array}{l}36.6 \pm 0.2 \\
31.9 \pm 0.2\end{array}$ & 38.5 & $\begin{array}{l}96 \% \\
84 \%\end{array}$ & $101 \%$ & 10 \\
\hline $\begin{array}{l}\text { IAEA, Soil } 6 \\
\text { (Austrian Soil) }\end{array}$ & 1.04 & $\begin{array}{l}0.96 \pm 0.04 \\
0.92 \pm 0.04\end{array}$ & 0.97 & $\begin{array}{l}92 \% \\
88 \%\end{array}$ & $94 \%$ & 10 \\
\hline $\begin{array}{l}\text { IAEA-375 } \\
\text { (Chernobyl Soil) }\end{array}$ & 0.30 & $\begin{array}{l}0.27 \pm 0.02 \\
0.21 \pm 0.02\end{array}$ & 0.23 & $\begin{array}{l}91 \% \\
70 \%\end{array}$ & $77 \%$ & 10 \\
\hline $\begin{array}{l}\text { Reagent Blank } \\
\text { (10 g equivalent) }\end{array}$ & - & $\begin{array}{l}0.014 \pm 0.006 \\
0.014 \pm 0.007\end{array}$ & $<0.1$ & - & - & - \\
\hline
\end{tabular}

1 The AMS results have not been corrected for U-238 interference. Quoted AMS uncertainties include counting statistics only.

2 Total sample mass digested. Five $10 \%$ aliquots of the digest were collected for AMS measurements, and the remaining was analyzed by alpha-spectrometry. 
Table 2. Pu-240/239 isotope ratios and $\mathrm{Pu}-241$ activity concentrations. Recent measurements of plutonium isotopes in IAEA reference materials by accelerator mass spectrometry (AMS) and alpha spectrometry at Lawrence Livermore National Laboratory. The results are compared to recently published results of Muramatsu, et al., measured by ICP-MS. ${ }^{32}$

\begin{tabular}{|c|c|c|c|}
\hline $\begin{array}{c}\text { IAEA } \\
\text { Sample } \\
\end{array}$ & $\begin{array}{c}240 / 239 \\
\text { ICP-MS result }^{3} \\
\%\end{array}$ & $\begin{array}{c}\text { 240/239 } \\
\text { AMS result }^{4} \\
\% \\
\end{array}$ & $\begin{array}{c}241 \text { activity } \\
\text { AMS result }{ }^{4,5} \\
(\mathbf{B q} / \mathbf{k g})\end{array}$ \\
\hline $\begin{array}{c}\text { IAEA-135 } \\
\text { (Irish Sea Sediment) }\end{array}$ & $21.1 \pm 0.4$ & $\begin{array}{l}21.3 \pm 0.6 \\
21.1 \pm 0.6\end{array}$ & $\begin{array}{l}2910 \pm 180 \\
2940 \pm 200\end{array}$ \\
\hline $\begin{array}{l}\text { IAEA, Soil } 6 \\
\text { (Austrian Soil) }\end{array}$ & $19.1 \pm 0.5$ & $\begin{array}{l}17 \pm 4 \\
18 \pm 4\end{array}$ & $\begin{array}{l}1 \pm 2 \\
6 \pm 3\end{array}$ \\
\hline $\begin{array}{c}\text { IAEA-367 } \\
\text { (Pacific Ocean Sediment) }\end{array}$ & - & $\begin{array}{l}32.0 \pm 0.6 \\
29.6 \pm 0.5\end{array}$ & $\begin{aligned} 116 & \pm 10^{6} \\
90 & \pm 8^{6}\end{aligned}$ \\
\hline
\end{tabular}

${ }^{3}$ ICP-MS results reported by Muramatsu, et al. (Ref. 32).

${ }^{4}$ The AMS results have not been corrected for U-238 interference. Quoted AMS uncertainties include counting statistics only.

5 Pu-241 activity on 8-AUG-1999.

${ }^{6}$ The IAEA provides an information value for Pu-241 activity in this sample of $170 \mathrm{~Bq} / \mathrm{kg}$ referenced to 1 JAN-1990 (see Ref. 45). Decayed to 8-AUG-1999 this information value becomes $107 \mathrm{~Bq} / \mathrm{kg}$. 
Submitted to Nuclear Instruments and Methods B, as part of the proceedings of the $8^{\text {th }}$ International Conference on Accelerator Mass Spectrometry, Vienna, 1999.

\section{Bibliography}

1 D. M. Taylor, Environmental Plutonium in Humans, Appl Radiat Isotopes 46, 1245-1252 (1995).

2 R. J. Pentreath, The Analysis of Pu in Environmental Samples - a Brief Historical Perspective, Appl Radiat Isotopes 46, 1279-1285 (1995).

3 R. J. Cornett, T. Eve, A. E. Docherty, and E. L. Cooper, Plutonium in Freshwaters - Sources and Behaviour in the Ottawa River Basin, Appl Radiat Isotopes 46, 1239-1243 (1995).

4 P. J. Kershaw, K. E. Sampson, W. McCarthy, and R. D. Scott, The Measurement of the Isotopic Composition of Plutonium in an Irish Sea Sediment By Mass Spectrometry, J Radioanal Nucl Chem Art 198, 113-124 (1995).

5 K. O. Buesseler, The isotopic signature of fallout plutonium in the North Pacific, J Environ Radioact 36, 69-83 (1997).

6 P. J. Kershaw, D. C. Denoon, and D. S. Woodhead, Observations on the redistribution of plutonium and americium in the Irish Sea sediments, 1978 to 1996: concentrations and inventories, J Environ Radioact 44, 191-221 (1999).

7 A. B. Kersting, D. W. Efurd, D. L. Finnegan, D. J. Rokop, D. K. Smith, and J. L. Thompson, Migration of plutonium in ground water at the Nevada Test Site, Nature 397, 56-59 (1999).

8 L. C. Sun, C. B. Meinhold, A. R. Moorthy, E. Kaplan, and J. W. Baum, Assessment of plutonium exposure in the Enewetak population by urinalysis, Health Phys 73, 127-132. (1997).

9 R. A. Guilmette, Issues and research on the biochemistry of inhaled actinides, J Alloys Compounds 271, 66-71 (1998).

10 J. C. Nenot and J. W. Stather, The toxocity of plutonium, americium and curium (Pergamon Press, London, 1979).

11 M. E. Wrenn, N. P. Singh, and Y. H. Xue, Urinary Excretion of Pu-239 By the General PopulationMeasurement Technique and Results, Radiat Prot Dosim 53, 81-84 (1994).

12 B. Franke, R. Schupfner, H. Schuttelkopf, and D. H. R. Spennemann, Transuranics in Bone of Deceased Former Residents of Rongelap Atoll, Marshall Islands, Appl Radiat Isotopes 46, 1253-1258 (1995).

13 L. C. Sun, A. R. Moorthy, E. Kaplan, J. W. Baum, and C. B. Meinhold, Assessment of Plutonium Exposures in Rongelap and Utirik Populations By Fission Track Analysis of Urine, Appl Radiat Isotopes 46, 1259-1269 (1995).

14 W. C. Inkret, D. W. Efurd, G. Miller, D. J. Rokop, and T. M. Benjamin, Applications of thermal ionization mass spectrometry to the detection of Pu-239 and Pu-240 intakes, Int J Mass Spectrom 178, 113-120 (1998).

15 M. P. Krahenbuhl and D. M. Slaughter, Improving process methodology for measuring plutonium burden in human urine using fission track analysis, J Radioanal Nucl Chem 230, 153-160 (1998).

16 J. H. Shinn, D. N. Homan, and W. L. Robison, Resuspension studies in the Marshall Islands, Health Phys 73, 248-257. (1997).

17 D. L. Donohue, Strengthening IAEA safeguards through environmental sampling and analysis, J Alloys Compounds 271, 11-18 (1998).

18 B. Salbu, T. Krekling, and D. H. Oughton, Characterisation of radioactive particles in the environment, Analyst 123, 843-849 (1998).

19 W. Templeton, F. Harrison, J. Knezovich, N. Fisher, and D. Layton, Bioconcentration of Radionuclides in Marine Food-Web Organisms in Radionuclides in the Arctic Seas from the Former Soviet Union: Potential Health and Ecological Risks, edited by D. Layton, L. C. D. R. R. Edson, M. Varela, and B. Napier (Arctic Nuclear Waste Assessment Program (ANWAP), Office of Naval Research (ONR), 1997), p. 4-1/4-12.

20 P. K. Kuroda, Extraterrestrial Radioactivity, J Radioanal Nucl Chem Art 203, $591-599$ (1996).

21 V. T. Bowen, K. M. Wong, and V. E. Noshkin, Plutonium-239 in and over the Atlantic Ocean, J Mar Res 29, 1-0 (1971). 
Submitted to Nuclear Instruments and Methods B, as part of the proceedings of the $8^{\text {th }}$ International Conference on Accelerator Mass Spectrometry, Vienna, 1999.

22 A. Moorthy, C. J. Schopfer, and S. Banerjee, Plutonium from atmospheric weapons testing: fission rack analysis of urine samples., Anal Chem 60, 857A (1988).

23 L. Johansson and E. Holm, Determination of Trace-Amounts Pu-239 Using Fission Track Analysis, Nucl Instrum Meth Phys Res a 376, 242-247 (1996).

24 L. Johansson, C. Samuelsson, and E. Holm, Evaluation of the fission track analysis for determination of traceamounts of Pu-239, Nucl Instrum Meth Phys Res a 423, 453-460 (1999).

25 K. O. Buesseler and J. E. Halverson, The mass spectrometric determination of fallout 239Pu and $240 P u$ in marine samples., J Envir Rad 5, 425 (1987).

26 K. O. Buesseler, S. A. Casso, M. C. Hartman, and H. D. Livingston, Determination of Fission-Products and Actinides in the Black Sea Following the Chernobyl Accident, J Radioanal Nucl Chem Art 138, 33-47 (1990).

27 J. S. Crain and J. Alvarado, Hydride Interference On the Determination of Minor Actinide Isotopes By Inductively Coupled Plasma Mass Spectrometry, J Anal Atom Spectrom 9, 1223-1227 (1994).

28 R. Chiappini, J. M. Taillade, and S. Brebion, Development of a High-Sensitivity Inductively Coupled Plasma Mass Spectrometer For Actinide Measurement in the Femtogram Range, J Anal Atom Spectrom 11, 497-503 (1996).

29 J. M. B. Moreno, M. Betti, and J. I. G. Alonso, Determination of neptunium and plutonium in the presence of high concentrations of uranium by ion chromatography inductively coupled plasma mass spectrometry, J Anal Atom Spectrom 12, 355-361 (1997).

30 A. E. Eroglu, C. W. McLeod, K. S. Leonard, and D. McCubbin, Determination of plutonium in seawater using co-precipitation and inductively coupled plasma mass spectrometry with ultrasonic nebulisation, Spectrochim Acta Pt B-At Spec 53, 1221-1233 (1998).

31 J. S. Becker, H. J. Dietze, J. A. McLean, and A. Montaser, Ultratrace and isotope analysis of long-lived radionuclides by inductively coupled plasma quadrupole mass spectrometry using a direct injection high efficiency nebulizer, Anal Chem 71, 3077-3084 (1999).

32 Y. Muramatsu, S. Uchida, K. Tagami, S. Yoshida, and T. Fujikawa, Determination of plutonium concentration and its isotopic ratio in environmental materials by ICP-MS after separation using ion-exchange and extraction chromatography, J Anal Atom Spectrom 14, 859-865 (1999).

33 I. Rodushkin, P. Lindahl, E. Holm, and P. Roos, Determination of plutonium concentrations and isotope ratios in environmental samples with a double-focusing sector field ICP-MS, Nucl. Instrum. Methods Phys. Res. A, Accel. Spectrom. Detect. Assoc. Equip. (Netherlands) 423, 472-9 (1999).

34 G. Passler, N. Erdmann, H. U. Hasse, G. Herrmann, G. Huber, S. Kohler, J. V. Kratz, A. Mansel, M. Nunnemann, N. Trautmann, and A. Waldek, Application of laser mass spectrometry for trace analysis of plutonium and technetium, Kerntechnik 62, 85-90 (1997).

35 B. Eichler, S. Hubener, N. Erdmann, K. Eberhardt, H. Funk, G. Herrmann, S. Kohler, N. Trautmann, G. Passler, and F. J. Urban, An atomic beam source for actinide elements: Concept and realization, Radiochim Acta 79, 221-233 (1997).

36 M. Nunnemann, N. Erdmann, H. U. Hasse, G. Huber, J. V. Kratz, P. Kunz, A. Mansel, G. Passler, O. Stetzer, $\mathrm{N}$. Trautmann, and A. Waldek, Trace analysis of plutonium in environmental samples by resonance ionization mass spectroscopy (RIMS), J Alloys Compounds 271, 45-48 (1998).

37 K. Wendt, K. Blaum, B. A. Bushaw, C. Gruning, R. Horn, G. Huber, J. V. Kratz, P. Kunz, P. Muller, W. Nortershauser, M. Nunnemann, G. Passler, A. Schmitt, N. Trautmann, and A. Waldek, Recent developments in and applications of resonance ionization mass spectrometry, Fresenius J Anal Chem 364, 471-477 (1999).

38 L. K. Fifield, R. G. Cresswell, M. L. Ditada, T. R. Ophel, J. P. Day, A. P. Clacher, S. J. King, and N. D. Priest, Accelerator Mass Spectrometry of Plutonium Isotopes, Nucl Instrum Meth Phys Res B 117, 295-303 (1996).

39 L. K. Fifield, A. P. Clacher, K. Morris, S. J. King, R. G. Cresswell, J. P. Day, and F. R. Livens, Accelerator mass spectrometry of the planetary elements, Nucl Instrum Meth Phys Res B 123, 400-404 (1997).

40 J. S. Vogel, K. W. Turteltaub, R. Finkel, and D. E. Nelson, Accelerator Mass Spectrometry - Isotope Quantification At Attomole Sensitivity, Anal Chem 67, A353-A359 (1995). 
Submitted to Nuclear Instruments and Methods B, as part of the proceedings of the $8^{\text {th }}$ International Conference on Accelerator Mass Spectrometry, Vienna, 1999.

41 M. L. Roberts, G. S. Bench, T. A. Brown, M. W. Caffee, R. C. Finkel, S. Freeman, L. J. Hainsworth, M. Kashgarian, J. E. McAninch, I. D. Proctor, J. R. Southon, and J. S. Vogel, The LLNL AMS facility, Nucl Instrum Meth Phys Res B 123, 57-61 (1997).

42 J. E. McAninch and T. F. Hamilton, Measurement of plutonium and other actinides at the Center for Accelerator Mass Spectrometry: A comparative assessment of competing techniques, Lawrence Livermore National Laboratory, Report No. UCRL-ID-133118 (1999).

43 K. M. Wong, T. Jokela, and V. E. Noshkin, Radiochemical procedures for analysis of Pu, Am, Cs, and Sr in water, soil, sediments and biota samples, Lawrence Livermore National Laboratory, Report No. UCRL-ID116497 (1994).

44 J. R. Southon and M. L. Roberts, Ten years of sourcery at CAMS/LLNL_evolution of a Cs ion source, These proceedings. (1999). 